\title{
Seroprevalence of Brucellosis in Bovine
}

\author{
M.D. Shrimali, S.S. Patel*, H.C. Chauhan, B.S. Chandel, A.C. Patel, K.K. Sharma, \\ A.I. Dadawala, A.G. Bhagat, S.K. Mohapatra, R.S. Shinde and N.M. Shah
}
Department of Veterinary Microbiology and Department of Animal Biotechnology, Veterinary College, S.D.A.U., Sardarkrushinagar, India

*Corresponding author

\begin{tabular}{l} 
K e y w o r d s \\
Brucellosis, \\
Seroprevalence, \\
RBPT, i-ELISA, \\
Bovine \\
Article Info \\
Accepted: \\
$\begin{array}{l}\text { 17 October } 2019 \\
\text { Available Online: } \\
10 \text { November } 2019\end{array}$ \\
\hline
\end{tabular}

\section{A B S T R A C T}

Brucellosis is an important zoonotic disease and it cause significant reproductive losses in animals. The present study envisaged the appraisal of seroepidemiology of brucellosis in cattle and buffaloes by i-ELISA and RBPT. In present study a total 550 bovine serum samples screened for detection of Brucella specific antibodies. Out of 550 samples, $112(20.36 \%)$ and $75(13.64 \%)$ sera samples were detected positive for Brucella antibody by RBPT and i-ELISA, respectively. Species-wise seroprevalence was detected $21.67 \%$ and $14.55 \%$ in cattle and $18.50 \%$ and $12.33 \%$ in buffaloes by RBPT and i-ELISA, respectively. Sex wise higher rate of seroprevalance observe in Female $20.71 \%$ and $14.47 \%$ then males $18.81 \%$ and $9.90 \%$ by RBPT and i-ELISA, respectively. Overall sensitivity $74.67 \%$, specificity $90.45 \%$ and overall agreement $88.21 \%$ of RBPT by comparing with iELISA for detection of Brucella antibodies.

\section{Introduction}

Bovine Brucellosis is an infectious disease caused by Brucella abortus. It is a small, nonmotile, coccobacilli, Gram negative, facultative, intracellular bacterial organisms of the genus Brucella. Brucella is named after Sir David Bruce who, in 1886, first isolated the organisms from the spleen of a soldier at postmortem with what was then called Malta fever. The isolation of $B$. abortus from aborted cattle was carried out by Bang in 1897 (Mcmahan, 1944). The disease has a considerable impact on human and animal health, as well as socioeconomic impacts, especially in which rural income relies largely on livestock breeding and dairy products. It causes significant reproductive losses in sexually mature animals (Wadood et al., 2009). According to OlE, it is the second most 
important zoonotic disease in the world after rabies. The disease affects cattle, swine, sheep, goats, camels and dogs.

Brucella infection occurs through inhalation or ingestion of organisms via the nasal, oral and pharyngeal cavities or through conjunctiva or skin abrasions. The disease can also be transmitted by direct or indirect contact with infected animals, fetal membranes (Godfroid et al., 2005).

Humans are commonly infected through ingestion of raw milk, cheese or meat or through direct contact with infected animals, products of conception or aniaml discahrges (e.g., among shepherds, farmers and veterinarians) and through inhalation of infectious aerosols by workers in abattoirs and microbiology laboratories.

Brucellosis is a major cause of reproductive losses, abortion, placentitis, epididymitis and orchitis in animals. The symptoms and signs most commonly reported in human are fever, fatigue, malaise, chills, sweats, headaches, myalgia, arthralgia and weight loss (Kochar et al., 2007 and Mantur et al., 2007)

Diagnosis of a disease is of prime significance in order to identify, prevent and control of a disease. As signs and symptoms of brucellosis are unspecific, culture and serology are necessary for diagnosis (Colmenero et al., 1996). Cultural isolation and identification of the agent is the gold standard test for Brucella diagnosis, however, this process is risky, time consuming, laborious and not suitable for disease surveillance. Moreover, it is a high risk biological pathogen that requires laboratories with qualified staff and facilities and class 3 personal protective equipment PPE (Lage et al., 2008 and Poester et al., 2009). The Brucellosis diagnosis and surveillance almost entirely on serological tests, e.g., Rose Bengal Plate Test (RBPT),
Standard Tube Agglutination Test (STAT), indirect Enzyme Linked Immunosorbent Assay (i-ELISA), and Complement Fixation Test (CFT), that detect antibodies against Brucella antigens including lipopolysaccharides (LPS) and give indirect evidence of Brucella infection (Adone and Pasquali, 2013). Serological tests are relatively easy to perform and provide a practical advantage in detecting the prevalence of Brucella infection.

\section{Materials and Methods}

A total of 550 serum samples were collected from cattle (323) and buffaloes (227) from rural areas and organized farms belonging to five districts of Gujarat (Table 1).

\section{Rose Bengal Plate Test (RBPT)}

One drop $(0.03 \mathrm{ml})$ of serum was taken on a clean glass slide by micropipette. The antigen bottle was shaken well to ensure homogenous suspension and then one drop $(0.03 \mathrm{ml})$ of the RBPT antigen (IAH and VB, Hebbal, Bangalore). The antigen and serum were mixed thoroughly with sterile tooth picks and then the slide was rotated for four minutes and result was read immediately. Definite clumping/agglutination was considered as positive reaction, whereas no clumping/agglutination was considered as negative.

\section{Indirect-Enzyme Linked Immunosorbent Assay (i-ELISA) for cattle and buffalo}

Brucella Antibody Test Kit, ELISA along with the user's manual was procured from National Institute of Veterinary Epidemiology and Disease Informatics (NIVEDI) formerly Animal Disease Monitoring and Surveillance (ADMAS), Bangalore was used in the present study. The test was performed as per the protocol outlined in the user manual. 


\section{Comparison of sensitivity and specificity of} i-Elisa and RBPT

The comparative efficacy of RBPT to i-ELISA was determined with regards to their sensitivity, specificity and overall agreement in the diagnosis of brucellosis for detecting antibodies. A total of 550 (323 from cattle and 227 from buffalo) serum samples were tested by i-ELISA and compared with RBPT. Cross tabulation of RBPT with i-ELISA, considering i-ELISA as a gold standard test were recorded as per Samad et al., (1994) to determine relative sensitivity, specificity and overall agreement of RBPT.

\section{Statistical analysis}

The data were entered in Excel (Microsoft) and analyzed by chi-square test. Charts were constructed in Word (Microsoft) and in Excel. A Chi square $\left(\mathrm{X}^{2}\right)$ test was done to compare the prevalence of brucellosis (in per cent) between different attributes of the seroepidemiology of brucellosis. Significance was determined at 5 per cent level. The difference was considered statistically significant if the $p$-value was $<0.05$.

\section{Results and Discussion}

During the present investigation 550 serum samples were screened from Cattle (323) and buffaloes (227) for the presence of Brucella antibodies and of these, 112 samples were found positive by RBPT (Fig. 1) and 75 by iELISA (Fig. 2) with the overall seroprevalence rates of $20.36 \%$ and $13.64 \%$, respectively. Species wise seroprevalence recorded was $(21.67 \%$ and $14.55 \%)$ in cattle and $(18.50 \%$ and $12.33 \%)$ in buffaloes by RBPT and i-ELISA, respectively (Table 1). Hence, species wise cattle showed higher rate of Seroprevalence compared to buffaloes. However, no significant difference was observed statistically. Similarly, Aulakh (2008) reported over all Seroprevalence of
$18.26 \%$ in cattle and buffaloes from Punjab by ELISA. Gumber (2004) reported over all Seroprevalence of $22.5 \%$ in cattle and buffaloes in Punjab, by RBPT. Patel et al., (2015) reported $14.81 \%$ Seroprevalence by iELISA. However, in contrast to the present study higher rate of seroprevalence of $28.00 \%$ in cattle and buffaloes in Bangladesh have been reported by Ahmed et al., (2010) by ELISA. Kushwaha et al., (2015) also reported very high seroprevalence rate of $33.85 \%$, $32.61 \%$ and $30.90 \%$ in cattle and buffaloes by ELISA, RBPT and STAT, respectively. Whereas Sharma et al., (2015) detected $41.25 \%$ animals' positive by RBPT and $46.86 \%$ positive by ELISA in Gujarat. Basit $e t$ al., (2015) reported relatively higher rate of seroprevalence in buffaloes $(9.00 \%)$ compared to cattle $(5.00 \%)$.

Sexwise sera sample were collected from males (101) and female (449). Out of 101 males, $18.81 \%$ and $9.90 \%$ and 449 females, $20.71 \% 14.47 \%$ detected positive by RBPT and i-ELISA, respectively. Higher seroprevalence was observed in female than male by both test which corroborates the findings of Rahman et al., (2011) and Mangi et al., (2015).

Clinical status wise seroprevalence ranging from (15.04\% to $52.17 \%$ ) and $(9.95 \%$ to $34.78 \%)$ respectively by RBPT and i-ELISA. Overall clinical status wise seroprevalence observed was highest in previous history of abortion $(52.17 \%$ and $34.78 \%)$ and lowest was in clinically healthy (15.04\% and $9.95 \%)$, respectively by RBPT and i-ELISA. Sexwise, Specieswise and clinical status wise all showed significant differed $(\mathrm{P} \leq 0.05)$ in Gujarat. Patel et al., (2015) reported 18.30\% seroprevalence in animals with reproductive disorders. Dinka et al., (2013) reported the overall prevalence of reproductive disorders in the study area was $18.3 \%$, with bovine brucellosis (32.90\%), repeated breeding $(26.80 \%)$ and abortion (14.60\%). 
Table.1 Overall seroprevalence of Brucellosis in cattle and buffaloes

\begin{tabular}{|c|c|c|c|c|c|}
\hline \multirow[t]{2}{*}{ Attribute } & \multirow[t]{2}{*}{ No. of sample tested } & \multicolumn{4}{|c|}{ No. of sample found positive } \\
\hline & & RBPT & $\%$ & i-ELISA & $\%$ \\
\hline \multicolumn{6}{|c|}{ Species: } \\
\hline Cattle & 323 & 70 & 21.67 & 47 & 14.55 \\
\hline Buffalo & 227 & 42 & 18.50 & 28 & 12.33 \\
\hline Total & 550 & 112 & 20.36 & 75 & 13.64 \\
\hline \multicolumn{6}{|c|}{ Sex: } \\
\hline Male & 101 & 19 & 18.81 & 10 & 9.90 \\
\hline Female & 449 & 93 & 20.71 & 65 & 14.47 \\
\hline Total & 550 & 112 & 20.36 & 75 & 13.64 \\
\hline \multicolumn{6}{|c|}{ Clinical status: } \\
\hline $\begin{array}{l}\text { Previous history of } \\
\text { abortion }\end{array}$ & 69 & 36 & 52.17 & 24 & 34.78 \\
\hline Hygroma & 17 & 05 & 29.41 & 04 & 23.52 \\
\hline Orchitis & 12 & 03 & 25.00 & 02 & 16.66 \\
\hline Clinically Healthy & 452 & 68 & 15.04 & 45 & 9.95 \\
\hline Total & 550 & 112 & 20.36 & 75 & 13.64 \\
\hline \multicolumn{6}{|c|}{ Districts: } \\
\hline Banaskantha & 195 & 42 & 21.54 & 26 & 13.33 \\
\hline Patan & 43 & 19 & 44.19 & 09 & 20.93 \\
\hline Sabarkantha & 123 & 12 & 9.76 & 16 & 13.01 \\
\hline Surat & 90 & 24 & 26.66 & 14 & 15.55 \\
\hline Katchchh & 99 & 15 & 15.15 & 10 & 10.10 \\
\hline Total & 550 & 112 & 20.36 & 75 & 13.64 \\
\hline
\end{tabular}

Table.2 Sensitivity specificity and overall agreement of RBPT by comparing with i-ELISA for detection of Brucella antibodies in cattle and buffaloes

\begin{tabular}{|c|c|c|c|c|c|c|c|}
\hline \multirow{2}{*}{\multicolumn{2}{|c|}{ Test }} & \multicolumn{2}{|c|}{ i-ELISA } & \multirow[t]{2}{*}{ Total } & \multirow{2}{*}{$\begin{array}{c}\text { Sensitivity } \\
(\%)\end{array}$} & \multirow{2}{*}{$\begin{array}{c}\text { Specificity } \\
(\%)\end{array}$} & \multirow{2}{*}{$\begin{array}{c}\text { Overall } \\
\text { Agreement } \\
(\%)\end{array}$} \\
\hline & & Positive & Negative & & & & \\
\hline \multirow[t]{3}{*}{ RBPT } & Positive & 56 & 56 & 112 & \multirow[t]{3}{*}{74.67} & \multirow[t]{3}{*}{90.45} & \multirow[t]{3}{*}{88.21} \\
\hline & Negative & 19 & 419 & 438 & & & \\
\hline & Total & 75 & 475 & 550 & & & \\
\hline
\end{tabular}


Table.3 Sensitivity, specificity and overall agreement of RBPT by comparing with i-ELISA for detection of Brucella antibodies in cattle

\begin{tabular}{|c|c|c|c|c|c|c|c|}
\hline \multicolumn{2}{|c|}{ Test } & \multicolumn{2}{|c|}{ i-ELISA } & Total & $\begin{array}{c}\text { Sensitivity } \\
(\%)\end{array}$ & $\begin{array}{c}\text { Specificity } \\
(\%)\end{array}$ & $\begin{array}{c}\text { Overall } \\
\text { Agreement } \\
(\%)\end{array}$ \\
\cline { 3 - 8 } & Positive & Negative & & & & (\%) \\
\hline \multirow{2}{*}{ RBPT } & Positive & 33 & 37 & 70 & 70.21 & 86.59 & $\mathbf{8 4 . 2 1}$ \\
\cline { 2 - 5 } & Negative & 14 & 239 & 253 & & & \\
\cline { 2 - 5 } & Total & $\mathbf{4 7}$ & $\mathbf{2 7 6}$ & $\mathbf{3 2 3}$ & & & \\
\hline
\end{tabular}

Table.4 Sensitivity, specificity and overall agreement of RBPT by comparing with i-ELISA for detection of Brucella antibodies in buffaloes

\begin{tabular}{|r|c|c|c|c|c|c|c|}
\hline \multirow{2}{*}{ Test } & \multicolumn{2}{|c|}{ i-ELISA } & Total & $\begin{array}{c}\text { Sensitivity } \\
(\%)\end{array}$ & $\begin{array}{c}\text { Specificity } \\
(\%)\end{array}$ & $\begin{array}{c}\text { Overall } \\
\text { Agreement } \\
(\%)\end{array}$ \\
\cline { 3 - 7 } & Positive & Negative & & & & \\
\hline \multirow{2}{*}{ RBPT } & Positive & 23 & 19 & 42 & 82.14 & 90.45 & $\mathbf{8 9 . 4 3}$ \\
\cline { 1 - 5 } & Negative & 05 & 180 & 185 & & & \\
\hline & Total & $\mathbf{2 8}$ & $\mathbf{1 9 9}$ & $\mathbf{2 2 7}$ & & & \\
\hline
\end{tabular}

Fig.1 Rose Bengal Plate Test (RBPT) for detection of Brucella antibodies

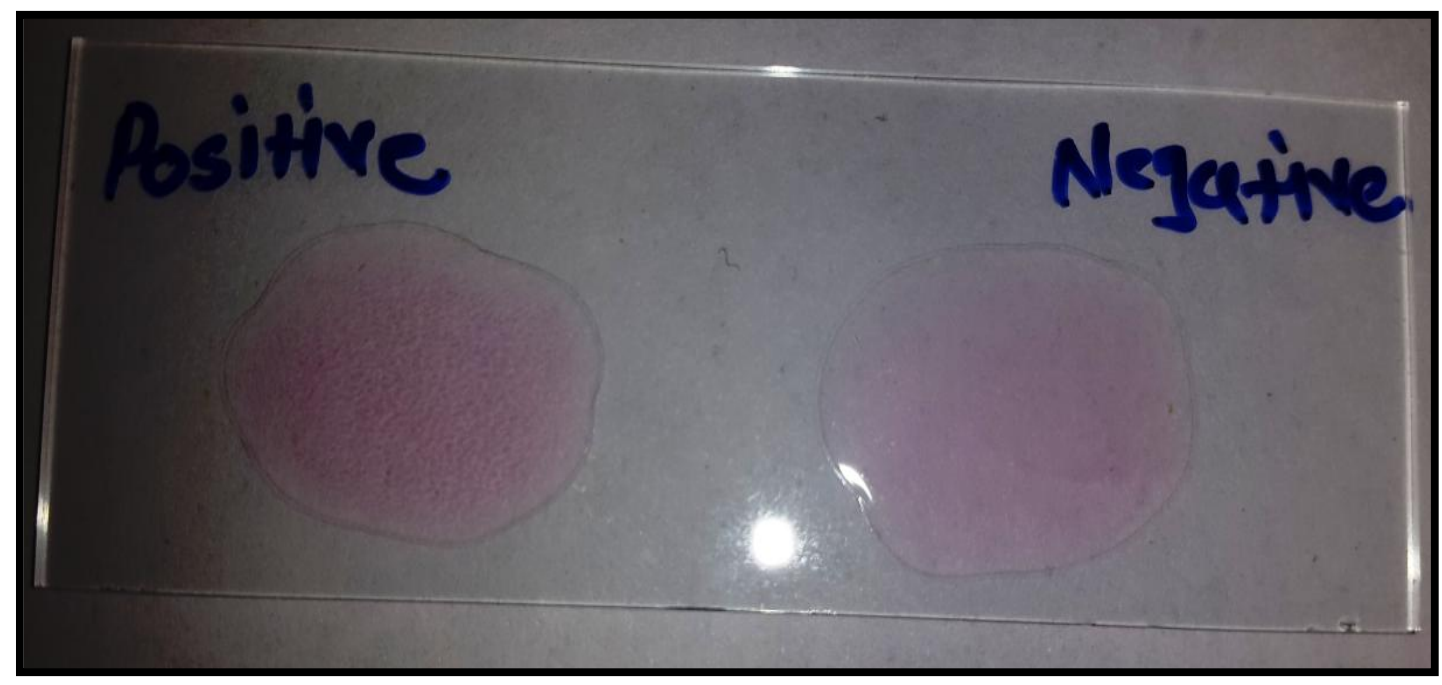


Fig.2 i-ELISA for detection of Brucella antibodies

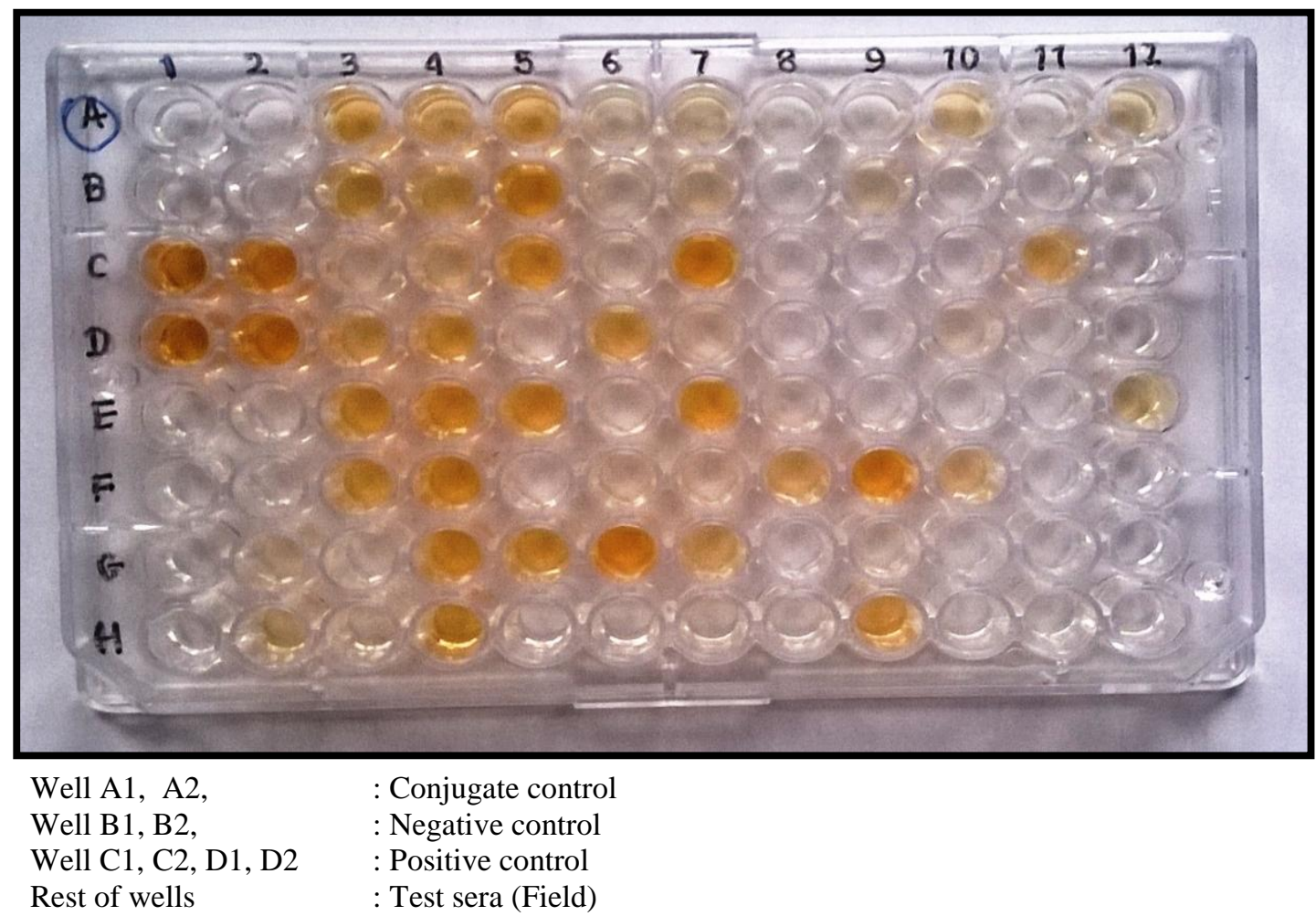

A total of 550 samples which included five districts viz., Banaskantha (195), Patan (43), Sabarkantha (123), Surat (90) and Katchchh (99). The seroprevalence detected in Banaskantha district was $(21.54 \%$ and $13.33 \%)$, in Patan district was $(44.19 \%$ and $20.93 \%)$ in Sabarkantha district was $(9.76 \%$ and $13.01 \%$ ), in Surat district was $(26.66 \%$ and $15.55 \%)$ and in Katchchh district was recorded $(15.15 \%$ and $10.10 \%)$, respectively by RBPT and i-ELISA. Patan showed higher rate of seroprevalence compared to other districts. All the districts showed seroprevalence significant differed $(\mathrm{P} \leq 0.05)$ except Katchchh districts of the Gujarat.

In present study, overall sensitivity, specificity and overall agreement of RBPT were $74.67 \%$, $90.45 \%$ and $88.21 \%$, respectively (Table 2 ) and Species-wise sensitivity of RBPT found was cattle $70.21 \%$ and buffaloes $82.14 \%$ whereas specificity was $86.59 \%$ in cattle and $90.45 \%$ in buffaloes (Table 3 and 4). Specieswise variation in sensitivity and specificity between both the tests may be due to the differences in the total number of sample tested from each species.

Various tests were compared with regards to their sensitivity and specificity in the diagnosis of bovine brucellosis. The sensitivity and specificity of RBPT were compared with i-ELISA. Indirect-ELISA is a sensitive test which can detect low concentrated antibody and test poor quality serum (Hobbs, 1985).

\section{Acknowledgement}

We are highly thankful to DBT, Govt. of India for financial assistance for the project. 


\section{References}

Adone, R. and Pasquali, P. (2013). Epidemiosurveillance of brucellosis. Revue Scientifique Technique (International office of Epizootics)., 32(1): 199-205.

Ahmed, Y.F., Sokkar, S.M., Desouky, H.M., Ghazi, Y.A., Amin, A.S. and Madboly, A.A. (2010). Pathological and molecular studies on mammary glands and supramammary lymph node of naturally Brucella infected buffalocows. Journal of Reproduction and Infertility., 1: 33-40.

Aulakh, H.K., Patil, P.K., Sharma, S., Kumar, H., Mahajan, V. and Sandhu, K.S. (2008). A Study on the Epidemiology of bovine brucellosis in Punjab (India) using milk-ELISA. Acta Veterinaria Brno., 77: 393-399.

Basit, A., Rahim, K., Shahid, M., Saleha, S., Ahmad, S. and Khan, M.A. (2015). Comparative study of brucellosis in different breeding practices of cattle and buffaloes. Journal of Infection and Molecular Biology., 3(4): 86-89.

Colmenero, J. D., Reguera, J. M., Martos, F., Sanchez-de-Mora, D., Delgado, M., Causse, M., Martin-Farfanm, A. and Juarez, C. (1996). Complications associated with Brucella melitensis infection. Medicine., 75:195-211.

Dinka, H. (2013). Major reproductive disorders of dairy cows in and around Asella town, Central Ethiopia. Journal of Veterinary Medicine and Animal Health., 5: 113-117.

Godfroid, J., Cloeckaert, A., Liautard, J. P., Kohler, S. and Fretin, D. (2005). From the discovery of the Malta fever's agent to the discovery of a marine mammal reservoir, brucellosis has continuously been a re-emerging zoonosis. Veterinary Research., 36: 313-326.

Gumber, S., Aradhana A., Dhand N.K. and
Sandhu, K.S. (2004). Village level study of bovine brucellosis in Punjab (India) by bulk milk analysis. Indian Journal of Animal Science., 74: 843844.

Hobbs, I.F. (1985). Comparison of indirect enzyme linked immunosorbent assay (ELISA) with the compliment fixation test (CFT) for serodiagnosis of bovine brucellosis. Newzealand Veterinary Journal., 33: 112-116.

Kochar, D. K., Gupta, B. K., Gupta, A., Kalla, A., Nayak, K. C. and Purohit, S. K. (2007). Hospital-based case series of 175 cases of serologically confi rmed brucellosis in Bikaner. Journal of Association of Physicians of India., 55: 271-275.

Kushwaha, N., Rajora, V.S., Mohan, A., Upadhyay, A.K. and Kumar, R. (2015). Comparison of serological tests for detection of Brucella antibodies in cattle of an organized dairy farm. Indian Journal of Animal Research., 50 (1): 69-74.

Lage, A.P., Poester, F.P., Paixão, T.A., Silva, T.A., Xavier, M.N., Minharro, S., Miranda, K.L., Alves, C.M., Mol, J.P.S. and Santos, R.L. (2008). Brucelose bovina: uma atualização. Revista Brasileira De Reproduo Animal., 32(3): 202-212.

Mangi, M.H., Kamboh, A.A., Rind, R., Dewani, P., Nizamani, Z.A., Mangi, A.R., Nizamani, A.R. and Vistro, W.A. (2015). Seroprevalence of brucellosis in Holstein- Friesian and indigenous cattle breeds of Sindh Province, Pakistan. Journal of Animal Health Production., 3(4): 82-87.

Mantur, B. G., Biradar, M. S., Bidri, R. C., Mulimani, M. S., Veerappa, K., Piaraylal, K., Patil, S. B. and Mangalgi, S.S. (2006). Protean Clinical manifestations and diagnostic challenges of human brucellosis in 
adults. 16 years' experience in an endemic area. Journal of medical microbiology., 55(7): 897-903.

McMahan, V. K. (1944). Brucellosis of cattle. Circular-222. Kansas Agricultural Experiment Station, Kansas State College of Agricultural and Applied Science. Manhattan, Kansas, USA.

Patel, B.C., Chauhan, H.C., Chandel, B.S., Dadawala, A.I., and Jain B.K. (2015). Seroprevalence and Molecular characterization of Brucella spp. in buffalo from North Gujarat, India. International Journal of Current Microbiology and Applied Sciences. 4(4): 174-180.

Poester, F., Figueiredo, V.C.F., Lobo, J.R., Gonçalves, V.S.P., Lage, A.P., Roxo, E., Mota, P.M.P.C., Müller, E.E. and Ferreira Neto, J.S. (2009). Estudos de prevalência da brucelose bovina no âmbito do Programa Nacional de Controle e Erradicação de Brucelose e Tuberculose: Introdução. Arquivo
Brasileiro de Medicina Veterinária e Zootecnia., 61(1): 1-5.

Rahman, M. S., Faruk, M. O., Her, M., Kim, J. Y., Kang, S. I. and Jung, S. C. (2011). Prevalence of brucellosis in ruminants in Bangladesh. Veterinarni Medicina., 56(8): 379-385.

Samad, A., Awaz, K.B. and Sarkate, L.B. (1994). Diagnosis of bovine traumatic reticulo peritonitis I: strength of clinical signs in predicting correct diagnosis. Journal of Applied Animal Research. 6(1): 13-18.

Sharma, K.K., Kalyani, I.H., Kshirsagar, D.P. and Patel D.R. (2015). Determination of herd prevalence of brucellosis using rose bengal plate test and indirect ELISA. Journal of Animal Research., 5(1):105-108.

Wadood, F., Ahmad, M., Khan, A., Gul, S. T. and Rehman, N. (2009). Seroprevalence of brucellosis in horses in and around Faisalabad. Pak. Vet. J., 29:196-198.

\section{How to cite this article:}

Shrimali, M.D., S.S. Patel, H.C. Chauhan, B.S. Chandel, A.C. Patel, K.K. Sharma, A.I. Dadawala, A.G. Bhagat, S.K. Mohapatra, R.S. Shinde and Shah, N.M. 2019. Seroprevalence of Brucellosis in Bovine. Int.J.Curr.Microbiol.App.Sci. 8(11): 1730-1737. doi: https://doi.org/10.20546/ijcmas.2019.811.201 